\title{
Equity in Higher Education: Evidences, Policies and Practices. Setting the Scene
}

\author{
Alberto Amaral
}

\section{Definition of Equity}

Education is a prerequisite for upholding democratic societies (Koucký et al., 2010), and higher education is associated with higher living standards, being a key factor of economic growth of societies (Blaug, 1987; Mincer, 1984). Equity of access to higher education has progressively become an increasingly prominent concern of education policies of governments and of international organisations.

Following Morton Deutsch, distributive justice (Homans, 1961) is concerned with the distribution of the conditions and goods which affect individual well-being' (Deutsch, 1975, p. 137) and equity and equality are its main basis (Espinoza, 2007). Although some authors use those terms interchangeably (Lerner, 1974; Warner, 1985) equity is a concept different from equality (Cook \& Hegtvedt, 1983). For Adams (1963), equity is related to the fairness of social exchanges, meaning that 'equity exists

\footnotetext{
A. Amaral $(\bowtie)$

Centre for Research in Higher Education Policies (CIPES),

Matosinhos, Portugal

e-mail: aamaral@cipes.up.pt

(C) The Author(s) 2022

O. Tavares et al. (eds.), Equity Policies in Global Higher Education, Issues in Higher Education, https://doi.org/10.1007/978-3-030-69691-7_2
} 
when the ratio between the investment and the return of an individual is perceived as being identical in terms of ratio to that of other people or groups' (Balassiano \& Salles, 2012, p. 271). Eckhoff (1974) defined five distinct principles of equality: objective equality, subjective equality, relative equality, rank order equality and equal opportunity. Under objective equality each recipient receives the same amount, which is the traditional notion of equality. Under subjective equality each recipient receives according to their needs, while relative equality (equality relative to individual contributions) corresponds to the notion of equity. Homans defined the principle of rank order equality as, "If the costs or investments of the members of one group are higher than those of another, distributive justice requires that their rewards should be higher, too' (Homans, 1958, p. 604). Equality of opportunities is difficult to apply due to the complexity of the term "opportunity" (Cook \& Hegtvedt, 1983, p. 221).

In higher education, equity or substantive equality is based on an understanding that academic performance and outcomes should be the same across groups of students, but it recognises that variables such as sex, class, socioeconomic status, race, and ethnicity will determine what students need to achieve these goals (American Association of University Women, 1998)' (as cited by Larkin \& Staton, 2001, p. 364). Therefore, equity does not mean treating all people the same way. In this chapter the term "equality" is used as meaning "subjective equality", which is equivalent to "equity".

\section{Equity and Supranational Organisations}

The relevance of equity in higher education is visible in the proliferation of declarations from international organisations. The Universal Declaration of Human Rights was proclaimed by the United Nations General Assembly in Paris on 10 December 1948. Paragraph 1 of article 26 addresses the problem of education as a fundamental right of humanity:

Everyone has the right to education. Education shall be free, at least in the elementary and fundamental stages. Elementary education shall be compulsory. Technical and professional education shall be made generally available and higher education shall be equally accessible to all on the basis of merit. 
The World Declaration on Higher Education for the Twenty-First Century: Vision and Action, proclaimed in the 1998 World Conference on Higher Education, also held in Paris, has a full paragraph under the heading of Equity of Access and affirms that no discrimination can be accepted:

In keeping with Article 26.1 of the Universal Declaration of Human Rights, admission to higher education should be based on the merit, capacity, efforts, perseverance and devotion, showed by those seeking access to it, and can take place in a lifelong scheme, at any time, with due recognition of previously acquired skills. As a consequence, no discrimination can be accepted in granting access to higher education on grounds of race, gender, language or religion, or economic, cultural or social distinctions, or physical disabilities.

The International Association of Universities (IAU), in a political statement on Equitable Access, Success and Quality in Higher Education adopted in its 13th General Conference, held in Utrecht in July 2008, urged that access to higher learning should be made possible to all regardless of race, ethnicity, gender, economic or social class, age, language, religion, location or[dis]abilites. It also considered that the goal of access policies should be successful participation in higher education, as access without a reasonable chance of success is an empty promise and argued that equitable access and academic excellence were essential and compatible aspects of a quality higher education. To fulfil these objectives, IAU proposed that different institutional models, flexible programmes of study as well as a variety of delivery modes must be available to allow individuals at all stages of life to move through higher education in a manner that suited their needs.

The OECD published an extensive report entitled Tertiary Education for the Knowledge Society (OECD, 2008), which dedicated a full chapter to achieving equity. In that report, equity in tertiary education (The designation "tertiary education" has frequently replaced the designation "higher education" to account for the diversification of the systems with institutions which are no longer universities)is defined as:

Equitable tertiary education systems are those that ensure that access to, participation in and outcomes of tertiary education are based only on individuals' innate ability and study effort. They ensure that the achievement of educational potential at tertiary level is not the result of personal and social circumstances, including of factors such as socio-economic status, gender, 
ethnic origin, immigrant status, place of residence, age or disability. (OECD, 2008, p. 13)

The European Commission (Commission of European Communities, 2006) also referred to the goals of equitable distribution of education resources. For the Commission, the concept of equity is close to the definition of equality of opportunity (Roemer, 1998). Equitable systems are those where the students' educational performance does not depend on ascriptive factors such as race, gender or family background. Or, in other words, educational outcomes will be the result only of the effort of individual students, not being influenced by other circumstances outside their control.

The European University Association (EUA) together with the European University Continuing Education Network (EUCEN) and the European Students' Union (ESU) has just published a report on Diversity, Equity and Inclusion in European Higher Education Institutions (EUA, 2019). The report establishes a distinction between equality and equity:

The term equality is linked to the idea that everyone has the same rights and should thus enjoy equal treatment and non-discrimination... The concept of equity goes further and includes needs-based support to level out relative disadvantage. It thus often comes along with measures such as positive action or positive discrimination. (EUA, 2019, p. 23)

Inclusion is often linked to social inclusion, where the challenge is to attain a social profile of the student body that corresponds to society at large. (EUA, 2019, p. 23)

These examples show that equity in access to higher education has received attention from many international organisations, although definitions of equity are not always fully coincident.

\section{Components of Equity}

The OECD (2008) considered that equity has two components: fairness, which implies that personal and social circumstances do not hinder achieving educational potential, and inclusion, which means that all are able to attain a basic standard of education. In a similar way, Marginson referred to two strategies to promote equity, the first one being to advance fairness' 
by changing the composition of participation', and the second one being inclusion by 'broadening the access and completion of under-represented groups' (Marginson, 2011, p. 23). And IAU recommended that governments should implement policies aiming at promoting 'equitable access, broadened participation and success in higher education' (IAU, 2008, p. 3).

The OECD argued, 'it is clear that equity in tertiary education is affected by inequities in preceding levels of education' (OECD, 2008, p. 13). Much of the unequal access to tertiary education is the result of the inability to achieve the necessary qualifications due to inequities in the preceding levels of education-for example, the choice of secondary school or the choice of a vocational school will strongly influence access to higher education-(Commission of European Communities, 2006; Koucký et al., 2010; Marcenaro-Gutierrez et al., 2007; Wößmann \& Schütz, 2006) and, in general, education systems have not been successful in breaking this link (OECD, 2008, p. 17).

The socioeconomic background of parents has been considered as one of the strongest predictors of students' academic achievement and attainment (Reardon, 2011). Many research studies on academic achievement have focused on the mechanisms through which differences between families lead to differences in students' academic success (Reardon, 2011). Income, parental educational attainment, family structure, school quality or choices are examples of some of these mechanisms. And Reardon concluded, 'the achievement gap between children from high- and lowincome families has grown substantially in recent decades. The income achievement gap is now considerably larger than the black-white gap, a reversal of the pattern fifty years ago' (Reardon, 2011, p. 112).

Bourdieu (1986) defined three forms of capital: economic capitalrelated to the financial status of the family, cultural capital-related to knowledge, skills, attitudes and values, and social capital-social connections linked to a complex of shared norms and values that promote social cooperation (Fukuyama, 1999). All the three forms of capital have influence on individuals' educational paths, creating diverse modes of inequality, and will have influence on the equity in access to higher education. Bourdieu's social reproduction thesis (Bourdieu \& Passeron, 1977) posits that the persistent inequalities in education, despite all the State efforts to eliminate or minimise them, are the result of the transmission to children of aesthetic codes, practices and dispositions [cultural capital] through the 
process of family socialisation, which confers an advantage to children from families with the highest cultural capital (Tzanakis, 2011).

\section{Relative and Absolute Changes in Participation}

The expansion of elite higher education systems towards mass systems and even universal systems was supposed to promote equity. As stated by Clancy \& Goastellec (2007, p. 144), 'one of the most frequently quoted generalisations in research into post-compulsory education is that expansion has not significantly reduced social class inequalities in access to higher education', a proposition confirmed by a number of researchers (Halsey, 1993; Kivinen et al., 2001; Shavit \& Blossfeld, 1993). However, Clancy (2001) argued that it is necessary to consider not only relative changes in access (fairness) but also absolute changes (inclusion).

Expansion of the higher education systems opened more places in institutions, thus allowing for an increased intake of students from deprived backgrounds. This was confirmed by studies of Clancy and Goastellec (2007) and Koucký et al. (2010). Clancy \& Goastellec argued that absolute changes pointed to the improvement of the participation of any particular group irrespective of what happened to other groups. And many governments claimed to have reduced access inequities if their education policies had increased the intake of students from deprived backgrounds.

However relative changes may present a different history as they are related to the positional character of education (see $\$ 6$ ). Koucký et al. (2010) analysed access to tertiary higher education in Europe for a sixtyyear period from 1950 to 2009 . Using the father's and mother's education and occupation, they defined four status groups of equal size to conclude that children from families in the higher status quarter still had 3.7 times higher chances to get tertiary qualifications than children from families in the lower quarter. And children from the top one tenth of higher status families still had $\mathbf{5 . 5}$ times higher chances than children from the one tenth of families with lower status. However, over those sixty years, chances to get tertiary qualifications increased considerably, both overall (from $12 \%$ in the 1950 s to $42 \%$ today) and for all social groups. 


\section{Massification and Diversification of the Systems}

In general, massification was accompanied by a diversification of the systems, which many governments considered an imperative to respond to the increasingly varied aspirations and capacities of an increasingly heterogeneous student population. Birnbaum (1983) distinguished between three types of diversification: systemic [different types of institutions in a higher education system], structural [institutional differences due to historical or legal reasons or in the internal structure of institutional power] and programmatic [diversified offer of study programmes and services].

Several authors considered that diversity played an important role when higher education systems moved from elite to mass. Stadtman (1980) argued that diversification was important for a number of reasons, including the offer of an increased number of alternative choices to students. He also referred to the adaptation of education to the wishes and individual capacities of students, which allows institutions to define their missions and the scope of their activities, answering to the complex and diversified social pressures, and making education virtually available to all.

More recently, van Vught (1996) referred to seven arguments in favour of diversity, including providing better responses to the needs of students and of the labour market; improving social mobility; allowing for increased efficacy of institutions and for low cost innovative experiments and making feasible the presence of elite institutions in a massified system. And Brennan and Naidoo (2007) argued that diversification was fundamental to create opportunities accessible for all and answering to a multitude of diverse interests and aspirations, since otherwise, many would be left out of higher education.

However, the diversification of higher education systems may create other types of inequity, as disadvantaged students may gain access to lower-status higher education institutions and/or programmes or they may represent a disproportionate percentage of those paying tuition fees (either in the public or private sector) (OECD, 2008, p. 19). Shavit et al. (2007) argued that massification tended to create new opportunities, but mainly of lower value. He considered that lower-tier opportunities allowed for the inclusion of students from deprived backgrounds who otherwise would not have access to tertiary education. And Koucký et al. (2010) argued that with expansion there has been a change in the character of inequalities, which have become 'more subtle and less discernible as they changed their focus from quantitative to qualitative characteristics', that is, 
the status of institutions and programmes has gained a new prominence. Studies by Chevalier and Conlon (2003) and Leathwood (2004)for the British system, Martins et al. (2005) and Tavares et al. (2008) for the Portuguese system or Groenez et al. (2003) for the Flemish Community of Belgium confirmed these findings.

\section{Positional Goods}

Much of what happens in terms of inequity of access to higher education is related to the fact that higher education is a positional good. Positional goods or status goods are goods or services which are demanded and bought because their possession or consumption confers social or other status to those acquiring them. Education is a positional good in the sense that it provides students with a competitive advantage when looking for employment, social standing and status (Marginson, 1998).

The value of positional goods depends strongly on their position in relation to others. Positional goods have a hierarchy of value, some being more valuable than others. Examples from education: a degree from Harvard University is more valuable than a degree from a community college; a degree from Cambridge University is more valuable than a degree from the University of Buckingham. In Portugal, a degree in Medicine is valuable as it remains scarce relative to demand and its value would decrease through massification. Places in highly reputed elite institutions such as Harvard or Cambridge or in study programmes such as Medicine are the most desired form of positional good as they offer a high probability of a successful career.

One of the characteristics of positional goods is that they are not only a scarce good, but they are also a scarce good in absolute sense (Marginson, 1998). As Hirsch put it in Social Limits to Growth, 'Positional competition ... is a zero-sum game. What winners win, losers lose' (Hirsch, 1976, p. 52). Hirsch offered a very good example of a spectator in a stadium who improved his view by standing on tiptoe. However, if everyone else did the same thing then everyone was worse off (Hirsch, 1976, p. 6) and the advantage of that spectator disappeared. Therefore, "positional goods" produced in higher education must be scarce. If the number of available places in medicine were to increase substantially, then the value of a degree in medicine would decrease. This explains why one of the main characteristics of American elite universities is their highly selective admissions system and their prestige in research (Dill \& Soo, 2004), or the very high 
positional value of study programmes such as medicine or dentistry that are frequently protected by imposing quotas (numerus clausus).

Marginson (2004) argued that scarcity by increasing competition for the best institutions and study programmes was a sign of prestige. For Marginson, 'the mechanisms of competition for prestige reproduce prestige itself and sustain the relative standing of institutions that produce it' (Marginson, 2004, p. 210). He further explained:

Elite institutions do not expand production to meet the full demand, like capitalist businesses. Their ultimate lodestone is not maximum market share or even maximum revenues; it is consumer preferment, social status and the academic status (especially in research) that helps to maintain their social status. (Marginson, 2004, p. 210)

In the positional competition game there are two parallel competitions: while students compete for a place in the best institutions and programmes, elite institutions compete for the best students. In this game increased competition reinforces the position of elite institutions and their position is not contestable. An example was the case of Civil Engineering programmes during the recent economic crisis in Portugal. During the crisis there was a strong decline of the building industry, which had reflection in the number of candidates for these programmes. However, while the most prestigious schools had no problem in filling their available places, all other institutions struggled and a few even closed their programmes.

In Portugal there is a centralised application process for the public sector, in which candidates have to rank up to 6 combinations of programme/ institution. Candidates are allocated to the available places based on their preferences and the application grade point average (GPA). The Ministry decided to allow institutions to establish a threshold GPA value for application to their programmes, higher than the legal minimum value. While the more prestigious institutions did this for their more coveted programmes, the other institutions adopted the minimum value and even suggested eliminating that minimum.

While elite institutions do not need to advertise their programmes or services, this is not the case of low and middle-level institutions, which have to spend resources on marketing hard to attract students to fill their vacancies. However, their success is always contestable and those institutions must maintain their marketing efforts every year, or even try to attract students by dropping prices or providing positive information on 
employment of their former graduates. This may create a race to the bottom among less prestigious institutions, where marketing and reliance on lower prices may degrade quality (Marginson, 2004).

As argued by Marginson (2004), social groups from deprived backgrounds are not in a good position to compete for positional goods, as the latter tend to be monopolised by social groups from privileged backgrounds. A consequence of this competition is the persistent inequality at the level of higher education. As Marginson explained:

Wealth follows prestige: wealthy families invest in high value positions in education so as to maintain their positions of social leadership, positions which provide necessary (though not sufficient) conditions for reproducing incomes and wealth in the next generation. Positional markets in higher education are a matching game in which the hierarchy of students/families is synchronised with the hierarchy of universities, and individual market choices are determined by status goals. (Marginson, 2004, p. 210)

\section{Maximally Maintained Inequality (MMI) and Effectively Maintained Inequality (EMI)}

It is well known that students whose parents come from well-educated and affluent backgrounds have an advantage over students coming from less educated parents. Achieving equality of opportunities for students of all social backgrounds has been an objective of many nations. It was expected that the effect of social background could be eliminated or at least minimised by the expansion of education systems. However, against all expectations, educational inequalities were surprisingly persistent in the face of the expansion of schooling at elementary and secondary levels (Erikson \& Jonsson, 1996; Featherman \& Hauser, 1978; Halsey et al., 1980; Shavit \& Blossfeld, 1993). Similar results can be found for higher education (Chesters \& Watson, 2013; Givord \& Goux, 2007; Lynch \& O'riordan, 1998; Roksa et al., 2007; Tsui, 2003).

It is argued that expansion is unlikely to reduce inequalities simply because students from privileged socioeconomic backgrounds are better placed than others to use the new educational opportunities offered by expansion (MMI-Maximally Maintained Inequality) and to obtain a qualitatively better kind of education at any given level (EMI-Effectively Maintained Inequality) (Boliver, 2011, p. 230). 
Raftery \& Hout (1993, p. 56) analysed the change in inequality among different cohorts of students resulting from the expansion of secondary education in Ireland to conclude that 'transition rates and odds ratios between social origins and educational transitions remain the same from cohort to cohort unless they are forced to change by increasing enrolments'. They suggested the term Maximally Maintained Inequality (MMI) for this hypothesis. They grounded the hypothesis (Raftery \& Hout, 1993 , p. 56-57) on the arguments that transition rates will remain constant in time if growth in the capacity of secondary and higher education only goes along with population growth and/or upgrading of social origins; that class odds-ratios will remain constant while transition rates increase for all social levels if expansion raises enrolments faster than demand; and that when demand for the privileged classes becomes saturated (near 100\%), the association between social origin and participation will be undermined (however, this only occurs if expansion in enrolment cannot be accommodated by alternative means, such as lower value opportunities; see Green, 1980; Sussman, 1967).

To summarise rather cynically, the lower classes can only take advantage of opportunities offered by expansion when the needs of the upper classes are fully satisfied. The existence of alternative routes can play a role, which will probably increase the odds of accessing higher education for students from lower backgrounds, even if in lower value opportunities. In the Portuguese case, the new vocational route is attracting mainly students from the lower classes who in general enter the labour market without having been in higher education. It is interesting to note that the expansion of secondary education in Ireland was not accompanied, at the time, by a similar expansion of enrolments in universities during the period 1970-1990, which resulted in a sharp decrease in transition rates, as many students completing secondary education could not find a place in a university. The problem was partially mitigated by offering new places in nonuniversity tertiary education, a lower value alternative.

Lucas (2001) noted that MMI failed in some cases such as the U.S. and the Netherlands because the effect of social background decreased before the strong condition for saturation (100\%) was achieved. However, Hout argued that inequality of educational opportunity may decrease prior to [national] saturation in part because some schools and colleges may reach saturation before others do... Aggregated over space and time, this phenomenon yields a decrease in inequality of educational opportunity prior to nationwide saturation' (Hout, 2006, p. 239). Hout therefore 
considered that the strong condition of saturation (100\%) at national level was excessive, and the decrease in inequality could occur when 'the proportion of successful students from privileged backgrounds exceeded $80 \%$-near saturation' (Hout, 2006, p. 239).

MMI describes inequality patterns but does not explain them. Raftery and Hout (1993) resorted to rational-choice assumptions for an explanation. They considered that the decision to continue in education was determined by the costs and benefits of continued education, as perceived by the student and her or his family. However, they deviate from pure rational-choice by considering that students may have different perceptions of the benefits of education due to 'unobserved effects such as ability and taste' (Raftery \& Hout, 1993, p. 57) or because families from deprived backgrounds are more sensitive to the costs of education. Alternatively, inequality patterns could be explained by behavioural economics, based on the idea that people deviate from rational and selfish choice (Vossensteyn \& de Jong, 2008). When students make their decisions, they do it under considerable uncertainty about the actual contents of their study programme and about the possibility of being employed after they finish their studies. As argued by Vossensteyn and de Jong, students make their decisions under the influence of background characteristics such as socioeconomic status, gender and ethnicity, their reference levels and loss aversion (Vossensteyn \& de Jong, 2008).

Lucas (2001) introduced a new hypothesis, which he designated as Effectively Maintained Inequality (EMI), to explain the endurance of inequality despite expansion. EMI posits that 'socioeconomically advantaged actors secure for themselves and their children some degree of advantage wherever advantages are commonly possible. On the one hand, if quantitative differences are common, the socioeconomically advantaged will obtain quantitative advantage; on the other hand, if qualitative differences are common the socioeconomically advantaged will obtain qualitative advantage' (Lucas, 2001, p. 1652). Before a particular level of schooling becomes saturated, the socioeconomically advantaged use their advantages to secure that level of schooling. Once that level of schooling approaches saturation, the socioeconomically advantaged look for qualitative differences and try to secure quantitatively similar but qualitatively better education. In other words, what counts is no longer entering that level of education but entering the best institutions and the best study programmes, which is consistent with the idea of education as positional good. 
This explains, for instance, why in the Portuguese higher education system, although the overall number of new places is higher than the number of candidates, segregation by socioeconomic background is still evident in the choice of highly selective study programmes such as Medicine. Recent data show that $73.2 \%$ of medical students (university) have parents with higher education, while $73.0 \%$ of students in nursing and health technologies (polytechnic) have parents with qualifications below higher education (see Sá et al. this book).

\section{Discussion}

In its 2008 report the OECD referred to two components of equity: fairness and inclusion. To promote fairness, governments should design policies aiming at convergence to a situation in which the percentage of participation of students from different family backgrounds would match the social composition of society. To promote inclusion, governments should design policies aimed at increasing the absolute number of students from deprived backgrounds entering higher education and graduating successfully. Therefore, two ways of measuring progress in equity have been used: relative changes of participation (equity/fairness) or absolute changes (inclusion) (Clancy \& Goastellec, 2007).

The positional character of higher education makes the objective of fairness extremely difficult to attain. Koucký et al. (2010), who analysed change in access to European higher education over a period of sixty years, concluded:

... it is not possible to postulate that quantitative expansion by itself decreases the differences in the attainment of tertiary education by children of various social strata ad groups and thus also the Inequality Index, though it contributes to this effect; although opportunities for all groups have been increasing, the mutual relationship of their levels has not changed too much. (Koucký et al., 2010, p. 32)

Marginson (2011) argued that the OECD reports show that it is more achievable and more fruitful to implement policies aimed at inclusion, rather than to increase fairness. He suggested, citing Bowden and Doughney (2010), privileging policies which aim at 'fostering first generation participation in higher education by building aspirations, confidence and educational capabilities, from early childhood to higher education' 
(Marginson, 2011, p. 34) and through higher education. As these additional students will come mainly from deprived backgrounds, this means increasing social support systems. These policies will be effective from the point of view of inclusion and may eventually, although slowly, contribute to increased fairness. As Marginson (2011, p. 34) recognised, 'social inequalities in education are organic to social relations and sustained from outside as well as inside regulated systems, in the reproduction of families, classes, professions, wealth and political power'. Therefore, instead of ignoring the role of status or choosing a direct confrontation it is more useful to find ways around it.

There are however some countries where affirmative policies were implemented aiming at increasing fairness in higher education. In this volume two examples of policies of affirmative action are presented and results critically analysed. These are the cases of the U.S. discussed by David Dill (this book) and of Brazil, discussed by Julio Bertolin and Tristan McCowan (this book).

\section{Tracking Systems}

There are some measures which could contribute to increase equity. One such measure consists of avoiding early tracking systems. There is tracking when students are grouped into distinct classes by academic ability, either in different schools or in different classes of the same school. In Europe some countries use separate secondary education schools for different objectives, some for vocational students and technical students and others for those aiming to go to university. In the U.S. all secondary education is provided in 'comprehensive high schools', a single destination for students from all social classes. However, inside the same high school students are assigned to different levels of the same course, or to a course with a curriculum that is either more or less rigorous (Lucas, 1999; Oakes, 2005). The OECD (2008) argued that there is evidence that tracked systems of secondary education contribute to widening inequalities in access to higher education. Tracked systems promote a stronger relationship between family background and student achievement, with deleterious effects on entry to higher education. The 2010 EUA Trends Report emphasised that early tracking seemed to reduce significantly intergenerational mobility (Sursock \& Smidt, 2010) and the 2010 Eurydice Report also mentioned that in systems with early tracking 'students from lower socio-economic status backgrounds are statistically more likely to 
"opt for" (or to have no option but) a vocational training route, from where it is more difficult to continue to higher education' (Eurydice, 2010 , p. 29).

\section{The Selective Nature of Mathematics}

Mathematics seems to play a very important role in sorting and stratifying students by race, ethnicity, gender and socioeconomic status (Davis \& Martin, 2008; Ellis, 2008; Gerdes, 1988; Gutiérrez, 2008; Kitchen, 2015; Kitchen et al., 2007; Lattimore, 2005; Martin, 2013; Spielhagen, 2011). In a joint position statement from the National Council of Supervisors of Mathematics (NCSM) and TODOS: Mathematics for ALL is an international professional organization that advocates for equity and excellence in mathematics education for ALL students-in particular, Latina/o students. It is stated:

Historically, mathematics and the perceived ability to learn mathematics have been used to educate children into different societal roles such as leadership/ruling class and labor/working class leading to segregation and separation (Berry et al., 2014; Davis \& Martin, 2008; Martin et al., 2010; Stanic, 1987; Tate, 1994; Woodson, 1933/2000). (NCSM, 2016, p. 2)

Many research studies show that success and achievement in mathematics is problematic. Indeed, as measured by the OECD's PISA study (OECD , 2015), the worst results were for mathematics, with $22.2 \%$ share of low achievers, followed by science with $20.6 \%$ and reading with a $19.7 \%$ (Eurostat, 2017). Even more concerning was the fact that, according to Kloosterman and Gorman (1990), by the middle grades, several students started to perceive mathematics as a special domain in which smart students were successful and other students failed. As students tended to maintain the level of mathematics skills with which they entered higher education (Parker, 2005) they considered that success or failure was the result of an ability. Consequently, Middleton and Spanias (1999) argued that (i) effort was perceived as rarely leading to a significant change in success patterns, (ii) motivations to mathematics were developed early and were stable over time, and (iii) there were inequities among groups of students that were differently taught to view mathematics.

As argued in the NCSM/TODOS position paper: 
The detrimental effects of tracking start early in elementary school with readiness labels and ability grouping structures that provide vastly different mathematical experiences. (NCSM, 2016, p. 2)

Brynes and Miller (2007) found that the socioeconomic status had direct effects on mathematics achievement, as students from favourable backgrounds had access to better-trained teachers, among other things, and tended to perform at higher levels than students from lower socioeconomic backgrounds did. Moreover, Hogrebe and Tate (2012) found that algebra performance was influenced by where students live. These studies showed that when high-quality mathematics education did not start in preschool and continued through the early years, children might get trapped in a trajectory of failure (Rouse et al., 2005; Starkey et al., 1999). Young children from low-income families showed specific difficulties in mathematics (Griffin et al., 1994). Working-class children in the U.K. were a year behind in simple addition and subtraction as early as 3 years of age (Hughes, 1981). Similarly, U.S. low-income children began kindergarten behind middle-income children and, although they progressed at the same rate on most tasks, they ended behind and made no progress in some tasks. For example, although they performed adequately on nonverbal arithmetic tasks, they made no progress over the entire kindergarten year on arithmetic story problems (Jordan et al., 2006).

Other research from across the world confirms the finding that there is greater variation in number knowledge among young children of lower socioeconomic background (Wright, 1991) and that there is a definite trend for students from lower socioeconomic backgrounds to perform at a lower level, which was more apparent for the difficult items (Thomson et al., 2005; see also West et al., 2001).

\section{The Admission System}

The admission system to higher education can also create problems. OECD explained:

... a number of young people are excluded from tertiary education because they do not meet the necessary qualifications. These include early schoolleavers and students who complete given tracks of secondary education, which do not give direct access to tertiary education. (OECD, 2008, p. 26) 
In many countries there are national examinations, either when leaving secondary education or when entering tertiary education. Equity problems may result from the fact that students from privileged backgrounds were likely to attend better schools or they could afford to pay private tutoring. For example, Choi et al. (2003) reported that in South Korea $56 \%$ of secondary school students had private tutoring in 2003 . Also providing competitive advantage, in Portugal there are some private colleges specialised in training students to have good performances in national examinations, which additionally inflate grades in those disciplines without national examinations, which also count in the calculation of the GPA considered for HE access (Baptista et al., this book). Therefore, to increase equity it is necessary to create alternative ways of acquiring eligibility for tertiary education (OECD , 2008), by broadening selection criteria beyond the traditional competition based on academic performance. Examples are special entrance criteria for mature students (over 23 or 25 years of age), the establishment of quotas for students from under-represented minorities or diverse forms of affirmative action (OECD, 2008).

In particular, it is well known that students from deprived backgrounds tend to enrol in higher proportion in vocational tracks of upper secondary education, which do not facilitate access to the best universities and programmes. This is the case of vocational education in Portugal or of the tracking system in the US. Therefore, it is highly advisable to create alternative pathways for access to tertiary education.

\section{Conclusion}

The commendable objective of many national educational policies intends to eliminate or at least to soften inequalities in the access to higher education. The positional nature of higher education makes this objective rather difficult to fulfil and, even when systems become mass systems or even universal systems, inequalities persist although they change in character: the question is no longer entering higher education but entering a particular institution or a particular study programme.

With the massification of higher education systems, there has been an increase in the number of students from deprived backgrounds entering higher education. However, diversification of the systems, usually by creating lower value opportunities (vocational programmes, short cycles, non-university institutions, etc.), has changed the nature of the game and 
the competition is no longer to enter a higher education institution but to enter the best institutions and the best programmes.

It is possible that inclusion policies, by promoting a progressive increase of people with higher education degrees, will contribute in a less contested even if slow way to progressively lower the present level of inequity.

\section{REFERENCES}

Adams, J. S. (1963). Towards an Understanding of Inequity. Journal of Abnormal and Social Psychology, 67(5), 422-436.

American Association of University Women. (1998). Gender Gaps: Where Schools Still Fail Our Children. American Association of University Women Educational Foundation. Marlowe \& Company.

Balassiano, M., \& Salles, D. (2012). Perceptions of Equity and Justice and Their Implications on Affective Organizational Commitment: A Confirmatory Study in a Teaching and Research Institute. Brazilian Administration Review, 9(3), 268-286.

Berry, R. Q., Ellis, M., \& Hughes, S. (2014). Examining a History of Failed Reforms and Recent Stories of Success: Mathematics Education and Black Learners of Mathematics in the United States. Race, Ethnicity, and Education, $17(4), 540-568$.

Birnbaum, R. (1983). Maintaining Diversity in Higher Education. Jossey-Bass.

Blaug, M. (1987). The Economics of Education and the Education of an Economist. New York University Press.

Boliver, V. (2011). Expansion, Differentiation, and the Persistence of Social Class Inequalities in British Higher Education. Higher Education, 61(3), 229-242.

Bourdieu, P. (1986). Forms of Capital. In J. G. Richardson (Ed.), Handbook of Theory and Research for the Sociology of Education (pp. 241-258). Greenwood Press.

Bourdieu, P., \& Passeron, J. C. (1977). Reproduction in Education, Society and Culture. Sage.

Bowden, M. P., \& Doughney, J. (2010). Socio-economic Status, Cultural Diversity and the Aspirations of Secondary Students in the Western Suburbs of Melbourne, Australia. Higher Education, 59(1), 115-129.

Brennan, J., \& Naidoo, R. (2007). Higher Education and the Achievement of Equity and Social Justice. In Higher Education Looking Forward Theme 2. European Science Foundation.

Brynes, J. P., \& Miller, D. C. (2007). The Relative Importance of Predictors of Math and Science Achievement: An Opportunity-Propensity Analysis. Contemporary Educational Psychology, 32(4), 599-629. 
Chesters, J., \& Watson, L. (2013). Understanding the Persistence of Inequality in Higher Education: Evidence from Australia. Journal of Education Policy, 28(2), 198-215.

Chevalier, A., \& Conlon, G. (2003). Does It Pay to Attend a Prestigious University? IZA Discussion Paper 848. Institute for the Study of Labor (IZA).

Choi, S.-K., Kim, Y.-B., Ryu, H.-G., Kim, H.-J., \& Lee, H.-S. (2003). Analysis of the Realities and Expenditure of Private Education. Korean Development Institute.

Clancy, P. (2001). College Entry in Focus: A Fourth National Survey of Access to Higher Education. Higher Education Authority.

Clancy, P., \& Goastellec, G. (2007). Exploring Access and Equity in Higher Education: Policy and Performance in a Comparative Perspective. Higher Education Quarterly, 61(2), 136-154.

Commission of European Communities. (2006). Efficiency and Equity in European Education and Training Systems. Commission Staff Working Document, SEC/2006/1096. Commission of European Communities.

Cook, K. S., \& Hegtvedt, K. A. (1983). Distributive Justice, Equity, and Equality. Annual Review of Sociology, 9(1), 217-241.

Davis, J., \& Martin, D. B. (2008). Racism, Assessment, and Instructional Practices: Implications for Mathematics Teachers of African American Students. Journal of Urban Mathematics Education, 1(1), 10-34.

Deutsch, M. (1975). Equity, Equality, and Need: What Determines Which Value Will Be Used as the Basis of Distributive Justice? Journal of Social Issues, 31(3), 137-149.

Dill, D., \& Soo, M. (2004). Transparency and Quality in Higher Education Markets. In P. Teixeira, B. Jongbloed, D. Dill, \& A. Amaral (Eds.), Markets in Higher Education: Rhetoric or Reality? (pp. 61-85). Kluwer Academic Publishers.

Eckhoff, T. (1974). Justice: Its Determinants in Social Interaction. Rotterdam Press. Ellis, M. (2008). Leaving no Child Behind Yet Allowing None Too Far Ahead: Ensuring (In)Equity in Mathematics Education through the Science of Measurement and Instruction. The Teachers College Record, 110(6), 1330-1356.

Erikson, R., \& Jonsson, J. O. (1996). Can Education Be Equalized? The Swedish Case in Comparative Perspective. Westview Press.

Espinoza, O. (2007). Solving the Equity-Equality Dilemma: A New Model for Analysis of the Educational Process. Educational Research, 49(4), 343-363.

EUA. (2019). Diversity, Equity and Inclusion in European Higher Education Institutions. European University Association.

Eurostat. (2017). Europe 2020 Indicators - Education. Retrieved from http://ec.europa.eu/eurostat/statistics-explained/index.php/ Europe_2020_indicators_-_education 
Eurydice. (2010). Focus on Higher Education in Europe: The Impact of the Bologna Process. Eurydice EACEA.

Featherman, D. L., \& Hauser, R. M. (1978). Opportunity and Change. Academic Press.

Fukuyama, F. (1999). The Great Disruption, Human Nature and the Reconstitution of Social Order. The Free Press.

Gerdes, P. (1988). On Culture, Geometrical Thinking and Mathematics Education. Educational Studies in Mathematics, 19(2), 13-162.

Givord, P., \& Goux, D. (2007). France: Mass and Class - Persisting Inequalities in Postsecondary Education. In Y. Shavit, R. Arum, A. Gamoran, \& G. Menahem (Eds.), Stratification in Higher Education: A Comparative Study (pp. 220-239). Stanford University Press.

Green, T. F. (1980). Predicting Behavior of the Educational System. Syracuse University Press.

Griffin, S., Case, R., \& Siegler, R. S. (1994). Rightstart: Providing the Central Conceptual Prerequisites for First Formal Learning of Arithmetic for Students at Risk for School Failure. In K. McGilly (Ed.), Classroom Lessons: Integrating Cognitive Theory and Classroom Practice (pp. 25-49). MIT Press.

Groenez, S., van den Brande, I., \& Nicaise, I. (2003). Cijferboek sociale ongelijkheid in het Vlaamse onderwijs. Een verkennend onderzoek op de Panelstudie van Belgische Huishoudens. LOA-rapport No. 10. Loopbanen doorheen Onderwijs naar de Arbeidsmarkt.

Gutiérrez, R. (2008). A “Gap Gazing” Fetish in Mathematics Education? Problematizing Research on the Achievement Gap. Journal for Research in Mathematics Education, 39(4), 357-364.

Halsey, A. H. (1993). Trends in Access and Equity in Higher Education: Britain in International Perspective. Oxford Review of Education, 19(2), 129-150.

Halsey, A. H., Heath, A. F., \& Ridge, J. M. (1980). Origins and Destinations: Family and Class Education in Modern Britain. Clarendon Press.

Hirsch, F. (1976). Social Limits to Growth. Harvard University Press.

Hogrebe, M. C., \& Tate, W. F. (2012). Place, Poverty, and Algebra: A Statewide Comparative Spatial Analysis of Variable Relationships. Journal of Mathematics Education at Teachers College, 3(2), 12-24.

Homans, G. C. (1958). Social Behavior as Exchange. American Journal of Sociology, 63(6), 597-606.

Homans, G. C. (1961). Social Behavior: Its Elementary Forms. Harcourt, Brace and World.

Hout, M. (2006). Maximally Maintained Inequality and Essentially Maintained Inequality: Crossnational Comparisons. Sociological Theory and Methods, 21(2), 237-252.

Hughes, M. (1981). Can Preschool Children Add and Subtract? Educational Psychology, 1(3), 207-219. 
IAU. (2008). Equitable Access, Success and Quality in Higher Education: A Policy Statement by the International Association of Universities. Adopted by IAU 13th General Conference, Utrecht, July.

Jordan, N. C., Kaplan, D., Oláh, L. N., \& Locuniak, M. N. (2006). Number Sense Growth in Kindergarten: A Longitudinal Investigation of Children at Risk for Mathematics Difficulties. Child Development, 77(1), 153-175.

Kitchen, R. (2015). Equity from an Assets-Based Perspective. James C. Kennedy Institute for Educational Success, Position Paper 3. Retrieved from https:// www.du.edu/kennedyinstitute/media/documents/kennedy_institute_policy_ paper_3.pdf

Kitchen, R. S., DePree, J., Celedón-Pattichis, S., \& Brinkerhoff, J. (2007). Mathematics Education at Highly Effective Schools That Serve the Poor: Strategies for Change. Lawrence Erlbaum Associates.

Kivinen, O., Ahola, S., \& Hedman, J. (2001). Expanding Education and Improving Odds? Participation in Higher Education in Finland in the 1980s and 1990s. Acta Sociologica, 44(2), 171-181.

Kloosterman, P., \& Gorman, J. (1990). Building Motivation in the Elementary Mathematics Classroom. School Science and Mathematics, 90(5), 375-382.

Koucký, J., Bartušek, A., \& Kovařovic, J. (2010). Who Gets a Degree? Access to Tertiary Education in Europe, 1950-2009. Charles University.

Larkin, J., \& Staton, P. (2001). Access, Inclusion, Climate, Empowerment (AICE): A Framework for Gender Equity in Market-Driven Education. Canadian Journal of Education, 26(3), 361-378.

Lattimore, R. (2005). African American Students' Perceptions of Their Preparation for a High-Stakes Mathematics Test. The Negro Educational Review, $56(2 \& 3), 135-146$.

Leathwood, C. (2004). A Critique of Institutional Inequalities in Higher Education or an Alternative to Hypocrisy for Higher Education Policy. Theory and Research in Education, 2(1), 31-48.

Lerner, M. (1974). The Justice Motive: 'Equity' and 'Parity' Among Children. Journal of Personality and Social Psychology, 29(4), 539-550.

Lucas, S. R. (1999). Tracking Inequality: Stratification and Mobility in American High Schools. Teachers College Press.

Lucas, S. R. (2001). Effectively Maintained Inequality: Education Transitions, Track Mobility, and Social Background Effects. American Journal of Sociology, 106(6), 1642-1690.

Lynch, K., \& O'riordan, C. (1998). Inequality in Higher Education: A Study of Class Barriers. British Journal of Sociology of Education, 19(4), 445-478.

Marcenaro-Gutierrez, O., Galindo-Rueda, F., \& Vignoles, A. (2007). Who Actually Goes to University? Empirical Economics, 32(2-3), 333-357.

Marginson, S. (1998). Competition and Diversity in the Reformed Australian Higher Education System. In L. V. Meek \& F. Q. Wood (Eds.), Managing 
Higher Education Diversity in a Climate of Public Sector Reform (pp. 81-96). Department of Employment, Education, Training and Youth Affairs.

Marginson, S. (2004). Australian Higher Education: National and Global Markets. In P. Teixeira, B. Jongbloed, D. Dill, \& A. Amaral (Eds.), Markets in Higher Education: Rhetoric or Reality? (pp. 207-240). Kluwer Academic Publishers.

Marginson, S. (2011). Equity, Status and Freedom: A Note on Higher Education. Cambridge Journal of Education, 41(1), 23-36.

Martin, D. B. (2013). Race, Racial Projects, and Mathematics Education. Journal for Research in Mathematics Education, 44(1), 316-333.

Martin, D. B., Gholson, M. L., \& Leonard, J. (2010). Mathematics as Gatekeeper: Power and Privilege in the Production of Knowledge. Journal of Urban Mathematics Education, 3(2), 12-24.

Martins, S. C., Mauriti, R., \& Costa, A. F. (2005). Condições Socioeconómicas dos Estudantes do Ensino Superior em Portugal. Direção Geral do Ensino Superior.

Middleton, J. A., \& Spanias, P. A. (1999). Motivation for Achievement in Mathematics: Findings, Generalizations, and Criticisms of the Research. Journal for Research in Mathematics Education, 30(1), 65-88.

Mincer, J. (1984). Human Capital and Economic Growth. Economics of Education Review, 3(3), 195-205.

NCSM. (2016). Mathematical Education Through the Lens of Social Justice: Acknowledgement, Actions, and Accountability. A Joint Position Statement from the National Council of Supervisors of Mathematics and TODOS: Mathematics for all. Retrieved from https://www.todos-math.org/assets/ docs2016/2016Enews/3.pospaper16_wtodos_8pp.pdf

Oakes, J. (2005). Keeping Track: How Schools Structure Inequality (2nd ed.). Yale University Press.

OECD. (2008). Tertiary Education for the Knowledge Society (Vol. 2). OECD.

OECD. (2015). PISA 2015: Results in Focus. Retrieved from http://www.oecd. $\mathrm{org} / \mathrm{pisa} /$ pisa-2015-results-in-focus.pdf

Parker, M. (2005). Placement, Retention, and Success: A Longitudinal Study of Mathematics and Retention. The Journal of General Education, 54(1), 22-40.

Raftery, A. E., \& Hout, M. (1993). Maximally Maintained Inequality: Expansion, Reform, and Opportunity in Irish Education, 1921-75. Sociology of Education, $66(1), 41-62$.

Reardon, S. F. (2011). The Widening Socioeconomic Status Achievement Gap: New Evidence and Possible Explanations. In R. J. Murnane \& G. J. Duncan (Eds.), Whither Opportunity? Rising Inequality and the Uncertain Life Chances of Low-Income Children (pp. 91-115). Russell Sage Foundation.

Roemer, J. E. (1998). Equality of Opportunity. Harvard University Press.

Roksa, J., Grodsky, E., Arum, R., \& Gamoran, A. (2007). United States: Changes in Higher Education and Social Stratification. In Y. Shavit, R. Arum, \& 
A. Gamoran (Eds.), Stratification in Higher Education: A Comparative Study (pp. 165-194). Stanford University Press.

Rouse, C., Brooks-Gunn, J., \& McLanahan, S. (2005). Introducing the Issue. The Future of Children, 15(1), 5-14.

Shavit, Y., Arum, R., \& Gamoran, A. (Eds.). (2007). Stratification in Higher Education: A Comparative Study. Stanford University Press.

Shavit, Y., \& Blossfeld, H. P. (1993). Persistent Inequality: Changing Educational Attainment in Thirteen Countries. Westview Press.

Spielhagen, F. R. (2011). The Algebra Solution to Mathematics Reform. Completing the Equation. Teachers College.

Stadtman, V. A. (1980). Academic Adaptations: Higher Education Prepares for the 1980s and the 1990s. Jossey-Bass.

Stanic, G. M. (1987). Mathematics Education in the United States at the Beginning of the Twentieth Century. In T. S. Popkewitz (Ed.), The Formation of School Subjects: The Struggle for Creating an American Institution (pp. 145-175). The Falmer Press.

Starkey, P., Klein, A., Chang, I., Dong, Q., Pang, L., \& Zhou, Y. (1999). Environmental Supports for Young Children's Mathematical Development in China and the United States. Paper Presented at the Meeting of the Society for Research in Child Development, Albuquerque, NM.

Sursock, A., \& Smidt, H. (2010). Trends 2010: A Decade of Change in European Higher Education. European University Association.

Sussman, L. (1967). Summary Review by the Rapporteur. In Social Objectives in Educational Planning. OECD.

Tate, W. F. (1994). Race, Retrenchment, and the Reform of School Mathematics. Phi Delta Kappan, 75(6), 477-484.

Tavares, D., Tavares, O., Amaral, A., \& Justino, E. (2008). Students' Preferences and Needs in Portuguese Higher Education. European Journal of Education, $43(1), 107-122$.

Thomson, S., Rowe, K., Underwood, C., \& Peck, R. (2005). Numeracy in the Early Years: Project Good Start. Australian Council for Educational Research (ACER).

Tsui, L. (2003). Reproducing Social Inequalities Through Higher Education: Critical Thinking as Valued Capital. The Journal of Negro Education, $72(3), 318-332$.

Tzanakis, M. (2011). Bourdieu's Social Reproduction Thesis and the Role of Cultural Capital in Educational Attainment: A Critical Review of Empirical Studies. Educate: Journal of Educational Research, 11(1), 76-90.

van Vught, F. A. (1996). Isomorphism in Higher Education? Towards a Theory of Differentiation and Diversity in Higher Education Systems. In V. L. Meek, L. Goedegebuure, O. Kivinen, \& R. Rinne (Eds.), The Mockers and Mocked: 
Comparative Perspectives on Differentiation, Convergence and Diversity in Higher Education (pp. 42-58). Pergamon.

Vossensteyn, H., \& de Jong, U. (2008). Student Financing in the Netherlands: A Behavioural Economic Perspective. In P. N. Teixeira, D. B. Johnstone, M. J. Rosa, \& H. Vossensteyn (Eds.), Cost-sharing and Accessibility in Higher Education: A Fairer Deal? (pp. 215-242). Springer.

Warner, J. (1985). Equity and Social Policy: Conceptual Ambiguity in Welfare Criteria. International Journal of Sociology and Social Policy, 5(2), 16-32.

West, J., Denton, K., \& Reaney, L. (2001). The Kindergarten Year. NCES 2001-023, U.S. Department of Education, National Center for Education Statistics. Government Printing Office.

Woodson, C. G. (1933/2000). The Mis-education of the Negro. African American Images.

Wößmann, L., \& Schütz, G. (2006). Efficiency and Equity in European Education and Training Systems. Analytical Report for the European Commission. Prepared by the European Expert Network on Economics of Education.

Wright, B. (1991). What Number Knowledge Is Possessed by Children Beginning the Kindergarten Year of School? Mathematics Education Research Journal, $3(1), 1-16$.

Open Access This chapter is licensed under the terms of the Creative Commons Attribution 4.0 International License (http://creativecommons.org/licenses/ by $/ 4.0 /$ ), which permits use, sharing, adaptation, distribution and reproduction in any medium or format, as long as you give appropriate credit to the original author(s) and the source, provide a link to the Creative Commons licence and indicate if changes were made.

The images or other third party material in this chapter are included in the chapter's Creative Commons licence, unless indicated otherwise in a credit line to the material. If material is not included in the chapter's Creative Commons licence and your intended use is not permitted by statutory regulation or exceeds the permitted use, you will need to obtain permission directly from the copyright holder.

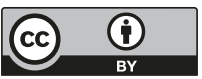

